\title{
The Iranian High School Students' Attitude toward CALL and the Use of CALL for EFL Receptive Skills
}

\author{
Mohammad Reza Talebinezhad \\ Shahreza Branch, Islamic Azad University, Iran \\ Masoud Azizi Abarghoui \\ Shahreza Branch, Islamic Azad University, Iran
}

\begin{abstract}
Computer-assisted language learning has received respectable amount of attention among researchers and language teachers. In this regard, innumerable large or small-scale projects blazed a trail for other teachers to follow. The present study is primarily concerned with the students' attitudes towards computer-assisted language learning. Its main purpose is to investigate what the Iranian high school students' general attitudes are towards computer- assisted language learning (CALL), and using CALL for teaching EFL receptive skills including reading and listening. The methodology employed a replication design and questionnaire approach. The findings demonstrate that most of the students have positive attitudes towards CALL and using it in language receptive skills teaching.
\end{abstract}

Index Terms - attitude, Computer-Assisted Language Learning (CALL), receptive skills

\section{INTRODUCTION}

Using computer, as a matter of fact, has been regarded as a revolution affecting all areas of human life throughout the history. Different communities continue to have much more interactions with computers. All aspects of life have been influenced by these changes. Along with this development, it becomes more and more important for different countries that their new generations being prepared to use, understand, and cope with computers in their lives and in their future work experiences.

With the extraordinary growth of computer technology, much greater attention has been paid to educational technologies in teaching and learning. Therefore, a great number of countries all around the world have incorporated computer into their educational programs, and tried to take advantage of the contribution of such an experiment in their training course. It is also one of the most attractive fields in the current teaching and learning trend and the matter which is generally thought about is that language learning could not be excluded from this.

Gradually, multimedia or computer-assisted language learning (CALL) has become an overwhelming trend and has been regarded as a major reform. It is greatly acknowledged that modern technology brings about noticeable changes into language courses (Xiong, 2008; Zhao and Liu, 2011).

Some scholars believe that CALL is in accordance with students' requirements as it supplies some functional and practical information. Taking a look at their findings, the first point coming to our mind is that CALL should be put into use more and more in various language classes. Being a stress-free environment and a more relaxed atmosphere comparing with the traditional classrooms can be considered as the main reason behind. Additionally, students' being dependent upon themselves results in more frequent interaction apt to take place between the learners. Also they spend much more time on cooperation having the classroom become a more student-centered than a teacher-centered environment because CALL increases their opportunities for working together.

According to some other research findings, computer-assisted language learning (CALL) is remarkable because the students gain more self-confidence in learning language by means of computer and also they believe that their language skills can be easily improved using computer, through developing their way of thinking.

In our country, Iran, some procedures have been adopted to integrate Computer Technology Resources (CTR) tools into the curriculum in recent years. Nowadays, the Ministry of Education has facilitated the integration of computerassisted language learning in high schools in order to make the conditions of students' education and training better and better and gain more advantages on a national level and also to increase the effectiveness, efficiency and creativity level of the future management system.

In great wonder, there seems to be a particular extent of resistance against CALL and its integration into our high schools' curriculum which resulted into an entire failure. There are some pupils who express denial at CALL that is why they believe it is something undesirable bringing some "luxurious" change forth. Moreover, as getting involved in CALL is an enduring challenge that calls for further time and persistence, there has to be remarkable number of 
students who would prefer not to agree with it. And also, some large numbers of questions were put forth concerning the attributed effectiveness of technology for teaching and learning.

Studies on the causes and reasons of such a resistance or failure should be considered of great importance to language researchers and teachers. Many experts think that they should take the students' ideas and opinions about CALL more seriously into consideration because students are not only potential operators of the language learning programs, but also are able to control their learning. So, conducting some studies concerning students' insights and impressions was called to mind.

Thus, there is a must to take a quick look on some special matters that may impede students' understanding the exact role of computer technology in their learning process. It is also imperative to analyze the influence of some factors like gender, environment, computer accessibility and familiarity on students' attitude towards use of computers. The information derived from these local researches or studies would help us in recognition of the main issues restricting the use of such worthy educational tools in high school classrooms.

Correspondingly, this study tries to assess the currently existing situation having to do with students' attitude and motivation and clarify the problems they may come across.

Studies on investigating students' attitudes towards CALL are of great importance due to the fact that such studies give close understanding of the value of the computer for our students. This research intends to investigate Iranian high school students' attitudes towards CALL and using it for teaching language receptive skills.

Although there have been some other researches on this issue especially during two past decades in Iran, however, there are some significant factors which should be put under emphasis to illustrate the attractiveness of more and more studies on it. Firstly, it is generally believed that students' resistance towards using CALL can be attributed to computer anxiety or computer phobia. In consequence of passage of time, computer-assisted language learning (CALL) has been developed; also computers have been being accepted as a part of family life and used by students all throughout the world resulting in decreasing amount of such a kind of anxiety or phobia. Secondly, as far as technology keeps growing, computer programmers will be more able to expand the attractive advantages of computer applications and software which leads into more interest on the part of students. Therefore, such studies on such an issue should be done following one after another.

There will be some suggestions or advice as the result of this study which may help the curriculum designers face the problems in integrating CALL into high schools EFL classrooms.

\section{A. Statement of the Problem}

English as a foreign language has lately found to be important to the Iranian people. That's why; it has become the language of choice for world communication, especially with globalization and tourism acceleration, and ease of travel. Due to that, people in Iran admit the need to study English more than ever before. Many students in Iran have a strong wish to become proficient and increase their English studies, believing that masterfulness in English can help them in earning a living, communicating with the entire world, and building a better future .Some sociologists argued that the multiple functions associated with the use of English in Iran have caused English to attain a dominant position in people's mainstream desire.

There is a huge amount of research that attempts to evaluate CALL from a variety of aspects. Chapelle (2003) categorizes the researches in CALL according to their focus of attention into three classes including the ones concentrate on the educational software, the learning task or task pedagogy and finally the pupils. While the majority of these studies respecting this issue focus on software design, looking for the possibilities and strategies with the greatest obtained success, the others examine the learning tasks identifying how to structure them to provide ideal conditions for learners' learning. Just a small number of them put the learners and their way of interaction with the computers and the given software under emphasis. Moreover, fewer studies take learner differences such as personal attitudes into account.

However, the attitudes of learners toward CALL could play an important role in language acquisition. Unfortunately, high school students and teachers within Iran lack important information in this area. For this reason, a research study which investigates learners' attitudes toward CALL in Iran may provide an empirical base for future studies on EFL learners' attitudes toward CALL.

In addition, as more and more institutions are being wired and initiating attempts to integrate CALL applications into their future accomplishments, it is important to assess users' attitudes and reflections and implement those tools based on a sound rationale.

Liaw (2002) found out that the more positive attitude individuals have towards computer-based learning, the greater behavioral intention they will have to use it and Ayres (2002) believed that those students who show high motivation and think of CALL as something required should also consider it as having a prominent role in the coursework.

Acknowledging the fact that effective exploitation of CALL and achieving the intended goals rely heavily on the students' attitude, this study aims to explore students' attitudes towards CALL.

\section{B. Purpose and Scope of the Study}

Probing attitudes directing at computer-assisted language learning was regarded as the main objective of the present study among a sample including 106 Iranian high school students. This study is different from prior studies related to CALL in that it was not concerned with how CALL affects student achievement; instead, the researcher investigated 
attitudes of learners toward computers in general and, more specifically, toward the use of computers when learning language receptive skills.

Therefore, inquiring into the two research questions below can be the scope of the current study:

1. What is the Iranian high school students' general attitude towards the use of computer-assisted language learning (CALL) in language instruction?

2. What is their attitude toward using CALL for teaching EFL receptive skills including listening and reading?

\section{Significance of the Study}

Computers and CALL materials have been integrated into the education philosophy and especially into English language curricula providing learners and teachers a broad spectrum of opportunities and resources for higher language achievement.

Research on the effectiveness of new technologies, particularly the use of computers in language teaching, has been an ongoing process. Notwithstanding many CALL researches on the software, the task and the pedagogy, this study appears to be important since it addresses students and attempts to pinpoint their attitude towards CALL. Moreover, most of the studies involve participants in higher education like university students but not young learners or high school students.

Attitudes can influence an individual's performance when learning CALL, including the student's cognition, emotion, and proficiency. Since attitudes toward CALL could be either positive or negative. Attitudes toward CALL have a great influence on further usage of it, as an example some scholars believe that negative attitudes toward CALL may hinder computer competency. Thus, a study on students' attitudes toward CALL could be useful in understanding the relationship between CALL and student proficiency in learning. Within the learning procedure one of the most prominent functions can be put into action by attitudes. Therefore, understanding how different attitudes could be used to foster English language learning in school can be thought of as something required. Thus, a study on learners' attitudes toward the use of computers in English language acquisition should enhance the ability of curriculum designers and teachers to understand the students' attitudes toward CALL. Furthermore, it will hopefully provide relevant information for educators about using CALL in similar contexts. It may be advantageous for researchers and teachers who are willing to conduct a similar study in the future. It is also hoped that some benefits can be derived of the current research study by the teachers who find it difficult to encourage their students to study outside the classroom and also by those students who are willing to take control and manage their own learning.

On account of not having a clear and complete knowledge of the role of technology and also its capacity of being implemented in teaching process by the majority of high school and educational institutes' teachers throughout our country ,Iran, yet, there might be some kinds of directions provided for them through this study.

\section{Definition of Key Terms}

Attitude: Wenden (1998) has defined attitude as evaluations, valued beliefs, motivations, what is believed to be acceptable, and approaching or avoiding responses towards something.

CALL: Though Chapelle (2001) expressed Computer- assisted language learning (CALL) as an expression, accepted by all participants in Toronto convention at 1983 and put to some regular yearly revision process, referring to the area relating technology and second language teaching and learning, this study embraces the one put forth by Egbert (2005) which means language learning process in any environment with, through, and around computer technology.

EFL: English as a foreign language (where English is not the official language but taught widely as a school subject).

\section{METHODOLOGY}

\section{A. Setting and Participants}

Iran Ministry of Education has been trying diligently to integrate CALL in every high school all around the country. Information Technology (IT) laboratories have been built in almost every high school recently. They are equipped with some appropriate hardware and software supplies including 20 Internet-connected PCs and also an information sharing system which enables the teacher to put his data on the students' monitors or send and receive files to and from them.

This study has been conducted in these IT laboratories in more than 12 separate boys' and girls' high schools in different counties, districts, and villages of Yazd, Kerman, and Fars provinces. The students who participated in this study including 45 boys and 61girls studying in first, second, third, and fourth( pre-university) classes in those abovementioned separate high schools.

\section{B. Instruments}

\section{Instructional Software DVD}

As mentioned previously, the students who participated in this study were studying in first, second, third, and preuniversity classes. These students were taught by means of a series of DVDs involving supplementary educational software named Khat-e-Sefid (The white Line) in a CALL environment for about one semester. This supplementary educational software has been designed according to the standardized published book of Islamic Republic of Iran Ministry of Education. These series have also been verified, approved and recommended to every high school English 
teachers all around the country by undersecretary of information and educational communication of the aforementioned ministry at 13 March, 2011.

\section{Questionnaire}

For gathering data, this study used a questionnaire as a data collection instrument. As_O'Maley and Chamot (1990) expressed comparing with other data collection instruments, questionnaire can be regarded as a feasible and applicable way of large scale or large population data gathering.

The second stage of this study included the questionnaire (Appendix A). At the end of the semester, immediately after finishing the course, the participants were given an attitude questionnaire and requested to fill it out. The objectives and aims of the present study were also talked about. Moreover, the students were appealed to express their ideas and opinions about using CALL for training and learning English in our high schools. Gathering data from the whole population, the high school students who were described before, was the most prominent reason for utilizing a questionnaire for the current study. With the exception of section one which included some open-ended response items, the questionnaire was mostly made up of Likert-scale items. As Turner (1993) pointed out in determining opinions and attitudes Likert-scale items are regarded as a useful and effective means.

This study utilized a questionnaire which was comprised of four parts. Gathering background information about the participants, their gender, age, schooling grade, location and some others including how often they use computer or whether they have passed a computer educational course or not, was the main aim of the first section.

The students' level of computer accessibility and familiarity were referred to in the second section of the questionnaire. In this part, the variable of accessibility was directed to in the first five questions and the second five referred to the variable of familiarity.

The third Section was comprised of fifteen questions concerning their general attitudes towards computer assisted language learning (CALL) and the final section of the questionnaire included five items to find out students' attitudes towards using CALL in instructing language receptive skills, reading and listening, separately.

TABLE 1

DISTRIBUTION OF QUESTIONS ON THE QUESTIONNAIRE

\begin{tabular}{|l|l|l|l|l|}
\hline Sections & Section I & Section II & Section III & Section IV \\
\hline $\begin{array}{l}\text { Question } \\
\text { types }\end{array}$ & $\begin{array}{l}\text { Background } \\
\text { information }\end{array}$ & $\begin{array}{l}\text { Accessibility and } \\
\text { Familiarity }\end{array}$ & $\begin{array}{l}\text { General attitudes towards } \\
\text { (CALL) }\end{array}$ & $\begin{array}{l}\text { Attitudes towards using CALL } \\
\text { teaching Reading \&Listening }\end{array}$ \\
\hline Number of Questions & $\mathbf{9}$ & $\mathbf{1 0}$ & $\mathbf{1 5}$ & $\mathbf{1 0}$ \\
\hline
\end{tabular}

The questionnaire was comprised of Likert-scale items (sections 2, 3, and 4) asking the participants to choose the item that expressed their ideas, opinions, and attitudes towards integrating computer technology in language learning best. These response items included 'strongly disagree', 'disagree', 'undecided', 'agree', and 'strongly agree'.

According to the following scale the mean values of the item responses were interpreted:

1) Strongly disagree was shown by the mean values between 1.00 and 1.80

2) Disagree was shown by the mean values between 1.81 and 2.60

3) Undecided was shown by the mean values between 2.61 and 3.40

4) Agree was shown by the mean values between 3.41 and 4.20

5) Strongly agree was shown by the mean values between 4.21 and 5.00

It is worth mentioning that, the research design was a replication based on a study done by Bulut and Abuseileek (2006) that investigated students' attitudes at King Saud University towards CALL and to evaluate the items suitability and the rubrics clarity some professors assessed the questionnaire outline format given by Bulut and Abuseileek (2006). There were some items reworded, some new ones added, ambiguous wordings modified, irrelevant items deleted due to their comments and suggestions taken into consideration. Moreover, making the items clear enough to the participants the grammatical mistakes were corrected. After some modification to the piloted items in the general attitude section, Cronbach's Alpha was run and determined to be .82.Although, due to the limited number of skills items, for the receptive skills section Cronbach's Alpha was not run.

After finalizing the items in the questionnaire, it was translated into the participants' native language, i.e. Persian, as it was assumed that it would be too difficult for students in high school level to comprehend. Then, to be sure of the translation, the questionnaire was translated into English again by a professional translator whose English proficiency was high enough. Minor corrections were made after the result of this back-translation.

\section{Data Collection Procedures}

The following procedures were followed. First, approval from the Director General of Education and Training Administration was obtained in a meeting. The researcher called some other English teachers who taught using the supplementary software to request their assistance in administering the questionnaires. The researcher's colleagues assisted him in distributing the questionnaires voluntarily. After about one semester, in March 2012, the English teachers administered the questionnaire to the students. Then they described the_study objective. The teachers emphasized to their students that not being a test this research instrument does not have any right or wrong answer. After completion, the surveys were returned to the researcher for data analyses. 


\section{Statistical Analysis}

The scores, generated by a 5-point Likert scale, determined each participant's overall attitude. For the purpose of understanding the students' attitude towards CALL, in the third section of the questionnaire, for each of the items students' responses were summed up, and for each and the total, the mean and the standard deviation were calculated. In a similar manner, for the two aforementioned language skills, in identifying the students' attitude the same method was also followed.

Describing and summarizing the collected data properties the descriptive statistics was used. For all descriptive and inferential statistics, the Statistical Packages for Social Sciences (SPSS) version 11.5 was put into use, except for nine open-ended response items in Section One.

\section{RESULTS}

\section{A. General Student Attitude toward CALL}

As the participants' general attitude toward using computers in language learning was the main issue of the first research question (What is the Iranian high school students' general attitude towards the use of computer-assisted language learning (CALL) in language instruction?), identifying the students' general attitude toward CALL was firstly taken into consideration.

TABLE 2

DISTRIBUTION OF PARTICIPANTS BY GENERAL ATTITUDE

\begin{tabular}{|l|l|l|l|}
\hline Attitude & Frequency & Percentage & $\begin{array}{l}\text { Cumulative } \\
\text { percentage }\end{array}$ \\
\hline Low & 45 & 42.5 & 42.5 \\
\hline High & 61 & 57.5 & 100 \\
\hline Total & 106 & 100 & \\
\hline
\end{tabular}

The level of participants' attitude toward CALL was determined re-encoding their attitude according to the distance from the mean and dividing them into high and low classes depicted in Table 2, indicating that $57.5 \%$ of them show high attitudes toward CALL.

In order to answer the first research question, the third section of the attitude questionnaire which included a series of 15 items regarding general attitudes (See Appendix A) was also analyzed illustrated in Table 3.

TABLE 3

PARTICIPANTS' GENERAL ATTITUDE TOWARD CALL

\begin{tabular}{|c|c|c|c|c|c|c|c|c|c|c|c|c|}
\hline \multirow{2}{*}{ Item } & \multicolumn{2}{|l|}{1} & \multicolumn{2}{|l|}{2} & \multicolumn{2}{|l|}{3} & \multicolumn{2}{|l|}{4} & \multicolumn{2}{|l|}{5} & \multirow[t]{2}{*}{ Mean } & \multirow[t]{2}{*}{ SD } \\
\hline & Freq & $\%$ & Freq & $\%$ & Freq & $\%$ & Freq & $\%$ & Freq & $\%$ & & \\
\hline 01 & 6 & 5.7 & 8 & 7.5 & 26 & 24.5 & 36 & 34 & 30 & 28.3 & 3.72 & 1.12 \\
\hline 02 & 4 & 3.8 & 7 & 6.6 & 28 & 26.4 & 34 & 32.1 & 33 & 31.1 & 3.80 & 1.07 \\
\hline 03 & 3 & 2.8 & 14 & 13.2 & 31 & 29.2 & 34 & 32.1 & 24 & 22.6 & $\begin{array}{l}3.48 \\
\end{array}$ & 1.06 \\
\hline 04 & 7 & 6.6 & 3 & 2.8 & 48 & 45.3 & 28 & 26.4 & 20 & 18.9 & 3.49 & 1.04 \\
\hline 05 & 3 & 2.8 & 12 & 11.3 & 45 & 42.5 & 23 & 21.7 & 23 & 21.7 & 3.48 & 1.04 \\
\hline 06 & 8 & 7.5 & 11 & $\begin{array}{l}10.4 \\
\end{array}$ & 35 & 33 & 26 & 24.5 & 26 & 24.5 & 3.48 & 1.18 \\
\hline 07 & 4 & 3.8 & 16 & 15.1 & 43 & 40.6 & 23 & 21.7 & 20 & 18.9 & 3.17 & 1.07 \\
\hline 08 & 7 & 6.6 & 11 & 10.4 & 37 & 34.9 & 38 & 35.8 & 13 & 12.3 & 3.18 & 1.04 \\
\hline 09 & 5 & 4.7 & 10 & 9.4 & 36 & 34 & 32 & 30.2 & 23 & 21.7 & 3.45 & 1.07 \\
\hline 10 & 4 & 3.8 & 7 & 6.6 & 33 & 31.1 & 34 & 32.1 & 28 & 26.4 & 3.71 & 1.05 \\
\hline 11 & 5 & 4.7 & 12 & 11.3 & 43 & 40.6 & 24 & 22.6 & 22 & 20.8 & 3.46 & 1.08 \\
\hline 12 & 10 & 9.4 & 18 & 17 & 44 & 41.5 & 20 & 18.9 & 14 & 13.2 & 3.09 & 1.12 \\
\hline 13 & 4 & 3.8 & 6 & 5.7 & 31 & 29.2 & 38 & 35.8 & 27 & 25.5 & 3.74 & 1.02 \\
\hline 14 & 4 & \begin{tabular}{|l|}
3.8 \\
\end{tabular} & 11 & 10.4 & 30 & 28.3 & 42 & 39.6 & 19 & 17.9 & 3.48 & 1.02 \\
\hline 15 & 9 & 8.5 & 20 & 18.9 & 41 & 38.7 & 13 & 12.3 & 23 & 21.7 & 3.10 & 1.22 \\
\hline
\end{tabular}

As can be seen in Table 3, the overall mean for all the items included in this section was 3.45 on a five-point Likert scale; moreover, 11 of the 15 items on attitude questionnaire were found to have higher means than 3.45 which means that students who have been recently exposed to CALL in their language learning experience have a positive attitude toward their new experience in general. Therefore, students who have been recently exposed to CALL in their language learning experience hold positive and accepting attitudes toward computer-assisted language learning.

However, certain items had lower and higher means when compared with the students' general attitude overall mean. For example, Item 12 'It takes less time to explain something during CALL classes' had the lowest mean score (3.09). For this item, only $13.2 \%$ of the students 'strongly' agreed. Similarly, Item 15 'I do not have technical problems in using computers during CALL classes' and Item 07 'I feel comfortable enough to share my ideas in English during CALL classes' had lower means compared to other items on the questionnaire (3.10 and 3.17), respectively.

There were also some items which had noticeably higher means than the overall mean. Item 2 'After taking CALL courses, I know how to benefit from my PC to improve my English' had the highest mean score (3.80). 
This was followed by Item 13'I have become a better problem-solver after using the computer while learning English' and Item 1 'I can access extra information more easily during a CALL class' (3.74 and 3.72 respectively).

\section{B. Students' Attitude toward CALL for EFL Receptive Skills}

The response to the second research question is considered in this section. In order to address this research question (What is their attitude toward using CALL for teaching EFL receptive skills including listening and reading?) or in another word to identify the students' attitude toward the use of CALL for the basic language skills of listening and reading instruction separately, specific language skill items were provided to students who participated in this study.

TABLE 4

STUDENTS' ATTITUDE TOWARD CALL FOR LISTENING SKILL

\begin{tabular}{|c|c|c|c|c|c|c|c|c|c|c|c|c|}
\hline \multirow[t]{2}{*}{ Item } & \multicolumn{2}{|l|}{1} & \multicolumn{2}{|l|}{2} & \multicolumn{2}{|l|}{3} & \multicolumn{2}{|l|}{4} & \multicolumn{2}{|l|}{5} & \multirow[t]{2}{*}{ Mean } & \multirow[t]{2}{*}{ SD } \\
\hline & Freq & $\%$ & Freq & $\%$ & Freq & $\%$ & Freq & $\%$ & Freq & $\%$ & & \\
\hline 01 & 4 & 3.8 & 4 & 3.8 & 18 & 17 & 38 & 35.8 & 42 & 39.6 & 4.04 & 1.032 \\
\hline 02 & 4 & 3.8 & 8 & 7.5 & 28 & 26.4 & 43 & 40.6 & 23 & 21.7 & 3.69 & 1.018 \\
\hline 03 & 7 & 6.6 & 9 & 8.5 & 36 & 34 & 26 & 24.5 & 28 & 26.4 & 3.56 & 1.164 \\
\hline 04 & 1 & 0.9 & 3 & 2.8 & 31 & 29.2 & 33 & 31.1 & 38 & 35.8 & 3.98 & 0.926 \\
\hline 05 & 1 & 0.9 & 3 & 2.8 & 21 & 19.8 & 39 & 36.8 & 42 & 39.6 & 4.11 & 0.887 \\
\hline
\end{tabular}

1 = strongly disagree $2=$ disagree $3=$ undecided $4=$ agree $5=$ strongly agree

The general mean for Listening skill was 3.87, which means that students had a positive attitude toward CALL for Listening in general. Thus, Iranian high school students show a positive attitude toward using CALL for teaching listening.

Out of these five items, Item 5 'Listening via computers is more useful in understanding the content when supported with visual information' had the highest mean and the lowest standard deviation $(\mathrm{M}=4.11, \mathrm{SD}=.887)$. This shows that students find visual information support to listening beneficial which is quite easily possible in a CALL environment. The low standard deviation also shows that most of the 106 students included in this section homogeneously agree on the benefit of visual information support. On the other hand, Item 3 'I can understand everything the teacher says via headsets clearly during CALL classes' had the lowest mean score (3.56) among the items for Listening skill. However, such a mean with the maximum standard deviation (1.164) shows that students didn't have a good experience on hearing the teacher via headsets, possibly because of some factors like being novice or deficient equipment. Other items had mean scores that fell between the highest and the lowest mean scores just mentioned.

TABLE 5

STUDENTS' ATTITUDE TOWARD CALL FOR READING SKILL

\begin{tabular}{|l|l|l|l|l|l|l|l|l|l|l|l|l|}
\hline \multirow{2}{*}{ Item } & $\mathbf{1}$ & $\mathbf{2}$ & $\mathbf{3}$ & $\mathbf{4}$ & $\mathbf{5}$ & Mean & \multirow{2}{*}{ SD } \\
& Freq & $\%$ & Freq & $\%$ & Freq & \% & Freq & \% & Freq & \% & \\
\hline 01 & $\mathbf{3}$ & $\mathbf{2 . 8}$ & $\mathbf{8}$ & $\mathbf{7 . 5}$ & $\mathbf{2 1}$ & $\mathbf{1 9 . 8}$ & $\mathbf{3 1}$ & $\mathbf{2 9 . 2}$ & $\mathbf{4 3}$ & $\mathbf{4 0 . 6}$ & $\mathbf{3 . 9 7}$ & $\mathbf{1 . 0 8 2}$ \\
\hline $\mathbf{0 2}$ & $\mathbf{2}$ & $\mathbf{1 . 9}$ & $\mathbf{4}$ & $\mathbf{3 . 8}$ & $\mathbf{2 9}$ & $\mathbf{2 7 . 4}$ & $\mathbf{3 3}$ & $\mathbf{3 1 . 1}$ & $\mathbf{3 8}$ & $\mathbf{3 5 . 8}$ & $\mathbf{3 . 9 5}$ & $\mathbf{0 . 9 8 0}$ \\
\hline $\mathbf{0 3}$ & $\mathbf{7}$ & $\mathbf{6 . 6}$ & $\mathbf{1 4}$ & $\mathbf{1 3 . 2}$ & $\mathbf{2 9}$ & $\mathbf{2 7 . 4}$ & $\mathbf{2 5}$ & $\mathbf{2 3 . 6}$ & $\mathbf{3 1}$ & $\mathbf{2 9 . 2}$ & $\mathbf{3 . 5 6}$ & $\mathbf{1 . 2 2 7}$ \\
\hline $\mathbf{0 4}$ & $\mathbf{3}$ & $\mathbf{2 . 8}$ & $\mathbf{2}$ & $\mathbf{1 . 9}$ & $\mathbf{2 4}$ & $\mathbf{2 2 . 6}$ & $\mathbf{3 6}$ & $\mathbf{3 4}$ & $\mathbf{4 1}$ & $\mathbf{3 8 . 7}$ & $\mathbf{4 . 0 4}$ & $\mathbf{0 . 9 7 5}$ \\
\hline $\mathbf{0 5}$ & $\mathbf{2}$ & $\mathbf{1 . 9}$ & $\mathbf{2}$ & $\mathbf{1 . 9}$ & $\mathbf{2 5}$ & $\mathbf{2 3 . 6}$ & $\mathbf{3 8}$ & $\mathbf{3 5 . 8}$ & $\mathbf{3 9}$ & $\mathbf{3 6 . 8}$ & $\mathbf{4 . 0 4}$ & $\mathbf{0 . 9 2 5}$ \\
\hline
\end{tabular}

On the part of reading skill, the general mean score for this group was 3.91, and this also shows that the students had a positive attitude toward CALL. Thus, Iranian high school students also show a positive attitude toward using CALL for teaching reading.

According to the data provided in Table 5, the highest mean score regarding reading skill items was 4.04 for Item 4 'I prefer to study reading via computers' and Item 5 'Reading via computers is more interesting when supported with visual information'. As CALL for reading included annotated texts and electronic dictionary use, students had the opportunity to compare their new experience in that sense and found CALL activities for reading useful. They also ranked 'visual information' item at the same level, which means that students think that visual information which is easily presented via computers is supportive in their reading comprehension. The lowest mean score (3.56) was for Item $3^{6}$ In reading courses, listening to the written text helps me comprehend better as I can hear the intonation, stress, ...' which shows that the participants did not always want to have their reading in a complete CALL environment, even though they had higher mean scores for other reading-related items.

\section{DiSCUSSION AND CONCLUSION}

On the basis of the current study findings, it was revealed that students have a positive attitude towards integrating CALL into the curriculum in general. Moreover, investigating the students' attitude toward using CALL for teaching EFL receptive skills as the second step of this study, it can be inferred that the participants generally have a positive attitude toward CALL for listening and reading skills.

As Almahboub (2000) stated, "based on behavior and cognitive theories, students should like and favor the subject or the activities in the learning environment in order to develop positive attitudes toward learning" (p. 66). The findings of 
the present study suggest that attitudes toward using computers in learning English are generally positive; thus, teachers should encourage this change in attitude for all students.

In this regard, curriculum designers should work hard with teachers. They should be concerned that the curriculum for students has sufficient references to the use of CALL in teaching English. Those responsible for curriculum designing should make sure that each skill included in the English program is taught along with CALL. The designers and teachers should also make sure that what is taught to students in the classrooms should be related to what is taught in the CALL labs. Their roles should ensure that CALL labs are connected with external and internal facilities not only domestically but internationally, including using the Internet. It is their duty to make sure that the curriculum devotes more time or extra sessions to CALL classes to cover all skills being taught. This means that the same amount of time should be devoted to CALL as to other skills. They also should ensure that the curriculum provides additional courses for students with a modest computer background, but not at the expense of shortening the hours scheduled for CALL.

Administrators of the ministry of education should understand the students' need for CALL in English classes. Once they reach this understanding, they should be willing to provide enough lab facilities for CALL during classes and students' free time so they have adequate time to practice using a computer. The administrators are advised to purchase the latest versions of CALL software that does not conflict with the domestic culture, an opinion shared also by Alkahtani (2001) and Al-Shammari (2007). Moreover, their policy should be strict enough so as not to hire teachers who have no background in CALL.

\section{APPENDiX A ATtitude TOWARD COMPUTER-Assisted LANGUAGE LEARNING}

\section{Questionnaire}

The Questionnaire On Investigating the Iranian high school students' attitude toward Computer-Assisted Language Learning

This questionnaire is going to investigate your attitude toward Computer-Assisted Language Learning (CALL) in English language classes. Your answers will be treated as strictly confidential and will be used only for this research. This questionnaire is divided into four sections. Please answer the items as honestly as possible. Your cooperation in completing this questionnaire is greatly appreciated.

With special thanks Masoud Azizi

\section{Section One}

\section{Background Information}

Please check $\square$ the appropriate choices and provide your answers below.

1. Age: 15-16 [ ] 16-17 [ ] 17-18 [ ] 18-19 [ ] +19 [ ]

2. Gender: Male [ ] Female [ ]

3. Schooling grade: First [ ] Second [ ] Third [ ] Pre-University (Fourth) [ ]

4. Location: Village [ ] District [ ] County [ ]

5. Do you own a Personal Computer (PC)? Yes [ ] No [ ]

6. How much proficient are you in using computer?

Very weak [ ] Weak [ ] Average [ ] Good [ ] Very good [ ]

7. Have you passed a Computer Educational Course? Yes [ ] No [ ]

8. How often do you use computers? Please check $\square$ the appropriate option.
A) Less than once a week [ ]
B) 1-2 times a week [ ]
C) 3-4 times a week [ ]
D) 5 or more times a week [ ]

9. What do you use computers for? Please check $\square$ the appropriate options to indicate your frequency of use? Never $=1$ Sometimes $=2$ Often $=3$

1. Electronic mail [ $\left[\begin{array}{lll}1 & 2 & 3\end{array}\right]$

2. Computer Games [ $\left[\begin{array}{lll}1 & 2 & 3\end{array}\right]$

3. Online shopping [ $\left[\begin{array}{lll}1 & 2 & 3\end{array}\right]$

4. School researches $\left[\begin{array}{lll}1 & 2 & 3\end{array}\right]$

5. Typing homework [ $\left[\begin{array}{lll}1 & 2 & 3\end{array}\right]$

6. Entertainment (e.g. music, film, sport news, news papers, magazines) [ [ $\left.\begin{array}{lll}1 & 2 & 3\end{array}\right]$

7. Voice chat [ $\left[\begin{array}{lll}1 & 2 & 3\end{array}\right]$

8. Personal site or web blog [llll 123$]$

\section{Section Two}

For the following items, please circle the answer that best reflects your opinion. 


\begin{tabular}{|l|l|}
\hline I do not have adequate access to the computers. & 12345 \\
\hline No suitable educational software is available at schools. & 12345 \\
\hline No suitable training opportunities are provided at schools. & 12345 \\
\hline School management does not provide us with equipped and sufficient computer labs. & 12345 \\
\hline School management does not provide us with any specialized supervisor in computer labs. & 12345 \\
\hline I do not know how to make use of computers. & 12345 \\
\hline I did not receive sufficient training to make use of computers. & 12345 \\
\hline It is not easy for me to get the information from the computer. & 12345 \\
\hline It is not easy for me to get the computer to do what I want to do. & 12345 \\
\hline My interaction with the computers is not clear and understandable. & 12345 \\
\hline
\end{tabular}

1 = Strongly disagree 2 = Disagree 3 = Undecided 4 = Agree 5 = Strongly agree

\section{Section Three}

For the following items, please circle the answer that best reflects your opinion.

\begin{tabular}{|l|l|}
\hline I can access extra information more easily during a CALL class. & 12345 \\
\hline After taking CALL courses, I know how to benefit from my PC to improve my English. & 12345 \\
\hline CALL is a stress-free environment to learn English. & 12345 \\
\hline I can get more feedback in CALL classes. & 12345 \\
\hline CALL is a more casual way of learning. & 12345 \\
\hline I benefit more from the group/pair work in a CALL class. & 12345 \\
\hline I feel comfortable enough to share my ideas in English during CALL classes. & 12345 \\
\hline My achievement can be measured in different ways in a CALL class. & 12345 \\
\hline I can practice all language skills in a CALL environment. & 12345 \\
\hline I know more about how to use computers after having taken CALL courses. & 12345 \\
\hline I can understand everything we do in CALL classes. & 12345 \\
\hline It takes less time to explain something during CALL classes. & 12345 \\
\hline I have become a better problem-solver after using the computer while learning English. & 12345 \\
\hline CALL has helped me become an independent learner. & 12345 \\
\hline I do not have technical problems in using computers during CALL classes. & 12345 \\
\hline
\end{tabular}

1 = Strongly disagree 2 = Disagree 3 = Undecided 4 = Agree 5 = Strongly agree

\section{Section Four}

Attitude items for EFL receptive skills

For the following items, please circle the answer that best reflects your opinion.

STUDENTS' ATTITUDE TOWARD CALL FOR LISTENING SKILL

\begin{tabular}{|l|l|}
\hline I prefer computers to tape recorders in listening in listening classes. & 12345 \\
\hline Sound is clearer via computers in listening classes. & 12345 \\
\hline I can understand everything the teacher says via headsets clearly during CALL classes. & 12345 \\
\hline Computers help me identify the key words when listening is supported with visual activities. & 12345 \\
\hline Listening via computers is more useful in understanding the content when supported with visual information. & 12345 \\
\hline
\end{tabular}
1 = Strongly disagree 2 = Disagree 3 = Undecided 4 = Agree 5 = Strongly agree

STUDENTS' ATTITUDE TOWARD CALL FOR READING SKILL

It is easy to access the meaning of words while reading in CALL classes.

Computer activities make our job easier in reading textbooks.

In reading courses, listening to the written text helps me comprehend better as I can hear the intonation, stress...

I prefer to study reading via computers.

Reading via computers is more interesting when supported with visual information.

\section{REFERENCES}

[1] Al-Kahtani, S. A. (2001). Computer-Assisted Language Learning in EFL Instruction at Selected Saudi Arabian Universities. (Doctoral dissertation).The Internet TESL Journal, 11(7).

[2] Almahboub, S. F. (2000). Attitudes toward computer use and gender differences among Kuwaiti sixth-grade students. Doctoral dissertation, University of North Texas, Denton.

[3] Al-Shammari, M. H. (2007). Saudi English as a Foreign Language Learners' Attitudes toward Computer-Assisted Language Learning. Doctoral dissertation, West Virginia University, Morgantown.

[4] Ayres, R. (2002). Learner attitudes toward the use of CALL, Computer Assisted Language Learning Journal, 15 (3): 2, 1 -249.

[5] Bulut, D., \& AbuSeileek, A. F. (2006). Learner's Attitude toward CALL and Level of Achievement in Basic Language Skills. Journal of Institute of Social Sciences of Erciyes University, 23(2):112-129.

[6] Chapelle, C. A. (2001). Computer applications in second language acquisition: foundations for teaching, testing, and research. Cambridge: Cambridge University Press. 
[7] Chapelle, C. A. (2003). The potential of technology for language learning. Excerpted from English Language Learning and Technology, 35-68. Amsterdam: John Benjamins.

[8] Egbert, J. (2005). CALL essentials: principles and practice in call classrooms. Alexandria, Virginia: TESOL.

[9] Liaw, S. (2002). Understanding user perceptions of World-wide web environments. Journal of Computer Assisted Learning, 18 (2):137-148.

[10] O'Malley, J. M. \& Chamot, A.U. (1990). Learning strategies in second language acquisition.UK: Cambridge University Press.

[11] Turner, J. C. (1993). Situated motivation in literacy instruction. Reading Research Quarterly, 28(4), 288-290.

[12] Wenden, A. (1998). Learner Strategies for Learner Autonomy. Great Britain: Prentice Hall.

[13] Xiong, X. (2008). An investigation of the use of CALL by college English teachers: Perspectives in a Chinese normal university. Queensland: University of technology.

[14] Zhao, S. \& and Liu, M. (2011). Current Language Attitudes of Mainland Chinese University Students. Journal of language teaching and research, 2(5):963-969.

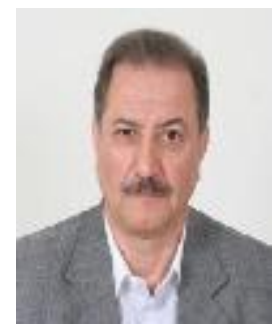

Mohammad Reza Talebinezhad is an Associate Professor of Applied Linguistics at Islamic Azad University, Shahreza Branch. He is also an associate faculty member at Sheikh Bahaee University, Iran.

Dr Talebinezhad received his BA in English Language and Literature, University of Isfahan in 1975. He then got his MA in TEFL from the University of Texas at Austin, USA in 1977. For his doctoral degree, Dr Talebinezhad was admitted to the University of Sheffield, UK, where he did his PhD in Applied Linguistics in 1994. He has widely published in Iranian as well as International professional journals such as Metaphor and Symbol, English Teaching Forum, Language Testing, IJAl, Language and Translation, Journal of Social Sciences, The International Journal of Humanities, and other local and international journals. Dr Talebinezhad has presented papers in International conferences such as AILA, 2000; Atiner, 2011; RAAM, 2002, 2001 in Paris and Tunis, EUROSLA, Switzerland, 2006; Multicultural Conference, 2007, China. In addition, Dr Talebinezhad has authored/coauthored eight books in related fields and ESP.

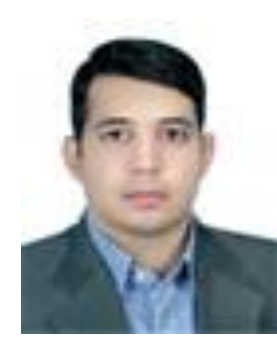

Masoud Azizi Abarghoui got his B.A in English Language and Literature from Sheikh Bahaee University (SHBU), Isfahan, Iran in 2007. Having participated in the M.A entrance exam, he was accepted at the Islamic Azad University, Shahreza branch, Iran to continue his studies in the field of Teaching English as a Foreign Language (TEFL).

$\mathrm{He}$ is currently working as a lecturer at University of Applied Science and Technology (UAST), Abarkouh Branch, Iran. He has also worked as an English teacher for the Ministry of Education and Training in Yazd, and different local institutes including Iran Language Institute (ILI) since then. His areas of research interest are inter-language pragmatics, language skills instruction and assessment, and computer assisted language learning. 